\title{
Testing the Long-Run Fisher Effect in Selected African Countries: Evidence from ARDL Bounds Test
}

\author{
Keho Yaya $^{1}$ \\ ${ }^{1}$ Department of Economics, National School of Statistics and Applied Economics, Côte d'Ivoire \\ Correspondence: KehoYaya, Department of Economics, National School of Statistics and Applied Economics, \\ Côte d'Ivoire. E-mail: yayakeho@ yahoo.fr
}

Received: August 26, 2015

Accepted: October 16, $2015 \quad$ Online Published: November 25, 2015

doi:10.5539/ijef.v7n12p168

URL: http://dx.doi.org/10.5539/ijef.v7n12p168

\begin{abstract}
This paper tests the validity of the Fisher hypothesis for a sample of ten African countries. Recognizing the possibility of spurious regression results, we undertook unit root and cointegration tests. We found nominal interest rates to be $\mathrm{I}(1)$ series while inflation rates are $\mathrm{I}(0)$ series. Hence, we employed the bounds test to cointegration. The results provide evidence supporting the full Fisher effect only in Kenya. In Cote d'Ivoire and Gabon, we found a positive but less than one-for-one reaction of nominal interest rates to changes in inflation rates, lending support to the partial Fisher effect. For the other seven countries, the results suggest no evidence of long-run relationship between nominal interest rates and inflation.
\end{abstract}

Keywords: fisher effect, interest rates, inflation, African countries

\section{Introduction}

The Fisher effect states that over the long-run, changes in the rate of expected inflation are perfectly absorbed by nominal interest rates, suggesting a one-to-one long term relationship between nominal interest rate and inflation rate. The implication of this hypothesis is that long run real interest rate is determined only by real factors such as the productivity of capital and investor time preference, and that monetary policy cannot affect the real interest rate (Payne \& Ewing, 1997; Atkins \& Coe, 2002). As interest rate is an important determinant of saving and investment, and therefore crucial for economic growth, the Fisher hypothesis has important policy implications for the behavior of interest rates and the efficiency of financial markets.

A growing literature has been devoted to test the validity of the Fisher hypothesis. The empirical evidence from this literature is however mixed and controversial across countries, data, interest rate variables and econometric techniques. While some studies (Bonham, 1991; Koustas \& Serletis, 1999; Ghazali \& Ramlee, 2003) found no evidence of cointegration between nominal interest rates and inflation, other studies (Granville \& Mallick, 2004, Gul \& Acikalin, 2008, Badillo et al., 2011) found evidence in favor of cointegration, but the coefficient on inflation is significantly less than one. This implies that real interest rates are negatively associated with expected inflation. With respect to African countries, most empirical studies of the Fisher hypothesis focused on Nigeria, South Africa and Namibia, with conflicting results.

In this study, we examine the validity of the Fisher hypothesis for ten African countries. The results of this study will provide useful knowledge to the monetary authorities about the relationship between inflation rate and interest rate. High inflation and interest rates are undesirable factors due to their negative effects on economic growth and social development. In many countries, the main goal of the central bank is the price stability. To achieve this goal, the nominal interest rate is used as the targeting instrument. We carried out the empirical analysis using the bounds testing approach to cointegration developed by Pesaran et al. (2001). This method can be applied irrespective of whether the regressors are $\mathrm{I}(0)$ or I(1). This represents a clear advantage over standard cointegration techniques. The remainder of the paper is organized as follows. Section 2 presents a review of the empirical literature on the Fisher effect. Section 3 describes the econometric methodology of the study. Section 4 analyses the empirical results and Section 5 concludes and suggests topics for further research.

\section{Literature Review}

The Fisher (1930) hypothesis suggests that there is a one-to-one relationship between interest rates and inflation in the long-run. This hypothesis has been tested extensively in the empirical literature. This was a result of the 
emergence of the literature on unit root and cointegration techniques. The empirical evidence is mixed across the estimation method, the sample period, the type of interest rate, countries, monetary policy regime and proxy for inflation. Studies by Bonham (1991), Koustas and Serletis (1999) and Ghazali and Ramlee (2003) found no evidence of cointegration between nominal interest rates and inflation. Other studies including Mishkin (1992), Crowder and Hoffman (1996), Evans and Lewis (1995), Granville and Mallick (2004) for UK, Gul and Acikalin (2008) for Turkey and Badillo et al. (2011) for a panel of 15 European Union countries found evidence in favor of cointegration between interest rate and inflation, but the coefficient on inflation is significantly less than one. This implies that real interest rates are negatively associated with expected inflation. The Fisher hypothesis has been validated by Garcia (1993) for Brazil, Thornton (1996) for Mexico, Payne and Ewing (1997) for Malaysia, Pakistan and Sri Lanka, and Atkins and Coe (2002) for US and Canada. Yuhn (1996) found evidence supporting the Fisher effect in US, Germany and Japan, but little evidence of it in UK and Canada. Inder and Silvapulle (1993) did not find evidence in favor of the Fisher effect in Australia.

Carneiro et al. (2002) used Johansen test to investigate the validity of the Fisher hypothesis in Argentina, Brazil and Mexico. Their results confirmed the validity of the Fisher effect for the cases of Argentina and Brazil. For Mexico, however, they found evidence that it was the inflation rate that adjusted to changes in interest rates in the period considered. Ur et al. (2004) used the Johansen cointegration approach to find empirical evidence supporting the Fisher Effect in Pakistan. Ito (2009) investigated the validity of the Fisher hypothesis in Japanese long-term interest rates over the period october 1987 to june 2006. The author considered three sample periods depending on each period's monetary policy regimes and found that the Fisher hypothesis is valid only for the period from October 1987 to June 1991. Ahmad (2010a) tested the presence of the long run Fisher effect for six countries namely India, Bangladesh, Pakistan, Sri Lanka, Kuwait and Saudi Arabia. Using the bounds testing approach, the estimation results indicate the presence of weak form of Fisher effect only in India, Pakistan, Kuwait and Saudi Arabia. However, no Fisher effect has been found in Bangladesh and Sri Lanka. Toyoshima and Hamori (2011) used panel cointegration analysis to test the Fisher effect for the US, the UK, and Japan. Their results support the full Fisher effect in these countries.

With respect to African countries, the studies by Obi et al. (2009), Muse and Alimi (2012) and Awomuse and Alimi (2012) provided evidence supporting the long-run partial Fisher effect for Nigeria, while Asemota and Bala (2011) and Ogbonna (2013) found no evidence of Fisher effect for Nigeria. Mitchell-Innes et al. (2008) also found evidence supporting the partial Fisher hypothesis over the period of inflation targeting (2000-2005) in South Africa. However Sheefeni (2013) found no relationship between interest rate and inflation in the case of Namibia.

Several explanations have been proposed for the mostly unfavorable evidence on the existence of a full Fisher effect. According to Tobin (1969), investors re-balance their portfolios in favour of real assets during high inflationary periods. Mundell (1963) also argued that there is no one-to-one adjustable relationship between nominal interest rate and expected inflation rate. Following the Mundell-Tobit effect, nominal interest rates would raise less than one-for-one with inflation. This is due to the fact that in response to inflation the public would hold less in money balances and more in other assets, which would drive interest rates down. Recently, some arguments contend that the inability to find evidence of Fisher effect originates from differences in econometric methods. During the 1970s, the lack of robust statistical methods certainly contributed to make results about the validity of the Fisherian theory quite controversial. Since the early 1980s, the innovations in the analysis of non stationary time series and the concept of cointegration motivated researchers to focus their attention on the stochastic properties of the time series and the problems of spurious regressions. Another strand of literature considers that structural changes and nonlinearities may explain the apparent failure of Fisher effect. It is well known by now that structural changes and nonlinearities in time series can cause deceptive in stationarity and cointegration testing. Mishkin (1992) noted that the Fisher equation between interest rate and inflation shifts with changes in monetary policy regimes. Bajo-Rubio et al. (2005) used a two-regime threshold cointegrtation model to find evidence of partial Fisher effect in the long run in the case of Spain for the period 1963-2002. According to the Authors the asymmetric response of nominal interest rates reflects the presence of some degree of money illusion in the financial market. Dutt and Ghosh (2007) used threshold cointegration methodology to revisit the Fisher effect for five European countries, namely Belgium, France, Germany, Italy and Sweden. They found evidence of partial Fisher effect for both Belgium and Germany but the effect is greater than one. The authors explained this result by the existence of tax effects. Westerlund (2008) used a panel cointegration test with multiple structural breaks and found some evidence supporting the Fisher hypothesis for 20 OECD countries for the period 1980-2004. Nusair (2008) examined the validity of the Fisher hypothesis for six Asian countries using the cointegration procedure developed by Gregory and Hansen (1996). The results 
indicate the presence of the full Fisher effect for Korea and the partial effect for Malaysia, Singapore, and Thailand. Hatemi-J and Irandoust (2008) tested the Fisher effect for Australia, Japan, Malaysia and Singapore using cointegration and time varying coefficient methods and found that the full Fisher effect is generally rejected. Hall et al. (2010) investigated the validity of Fisher effect for the US economy using cointegration test and time-varying coefficients method. They found strong support for Fisher hypothesis over the period 1960-2008. Ahmed (2010b) used nonlinear method to validate the Fisher effect for eight Asian countries. Phiri and Lusanga (2011) examined the validity of the Fisher effect in the case of South Africa using threshold cointegration techniques. They found significant Fisher effect only in the long-run. Arisoy (2013) tested the Fisher hypothesis in Turkey for the period 1987-2010 using cointegration test with structural break and time-varying coefficients approach, and found evidence supporting the weak form of the Fisher effect. Ucak et al. (2014) explored structural breaks in the Fisher effect for four EU member countries. Their results show that Fisher effects are more than one.

\section{Data and Econometric Methodology}

\subsection{Data and Model Specification}

The Fisher hypothesis states that there is a long run one-for-one relationship between nominal interest rate and expected inflation rate. This proposition is described by the Fisher identity:

$$
i_{t}=r_{t}^{e}+\pi_{t}^{e}
$$

where $i_{t}$ represents the nominal interest rate in period $\mathrm{t}, r_{t}^{e}$ is the ex-ante real interest rate, and $\pi_{t}^{e}$ is expected inflation rate. In absence of money illusion, a change in the expected inflation rate should be fully transmitted to the nominal interest rate, so that $r_{t}^{e}$ was approximately constant in the long run.

Under the usual assumption of rational expectations, the expected inflation rate equals the actual inflation rate plus mean-zero forecast error term $\varepsilon_{t}$ :

$$
\pi_{t}^{e}=\pi_{t}+\varepsilon_{t}
$$

Finally, the empirical equation to be estimated becomes:

$$
i_{t}=\alpha+\beta \pi_{t}+\mu_{t}
$$

where $\beta$ is the coefficient of interest, expected to equal one. An estimate of $\beta$ not significantly different from one indicates a strong form of Fisher hypothesis whereas a value lowers than one indicates a weak or partial Fisher effect.

The study uses annual data for a sample of ten African countries, namely Benin, Cameroon, Cote d'Ivoire, Gabon, Gambia, Ghana, Kenya, Nigeria, Senegal and South Africa.The variables under study are nominal deposit interest rate and inflation rate. Inflation rate is computed as the annual percentage change of the consumer price index. The data are taken from the World Development Indicators of the World Bank. Data are annual and the sample size is different depending on the availability of the data.

\subsection{Bounds Testing Approach to Cointegration}

Several econometric methods have been developed to investigate the long-run relationship between two or more time series variables. We have the residual-based procedure of Engle and Granger (1987), the Fully Modified Ordinary Least Squares (FMOLS) by Phillips and Hansen (1990), the Dynamic Ordinary Least Squares (DOLS) initially suggested by Saikkonen (1991) and Stock and Watson (1993), and the maximum likelihood cointegration method of Johansen (1988) and Johansen and Juselius (1990). All these techniques require the variables to be integrated of order one. Recently, a new cointegration technique has been developed by Pesaranet al. (2001) and based on autoregressive distributed lag (ARDL) models. This technique has certain econometric advantages over standard methods. It can be applied irrespective of whether the regressors are $\mathrm{I}(0)$ or $\mathrm{I}(1)$. This allows us to avoid the problem associated with conflicting results of the conventional unit root tests and the low power of these tests in small samples. It also solves the endogeneity problems and the inability to test hypotheses on the estimated coefficients in the long-run associated with the Engle-Granger two-step method. For these reasons, we use the ARDL bounds test to investigate the long-run relationship between nominal interest rate and inflation. 
The bounds test begins with an unrestricted vector autoregressive (VAR) in levels:

$$
Y_{t}=\mu+\sum_{j=1}^{p} \phi_{j} Y_{t-j}+\varepsilon_{t}
$$

where $Y_{t}=\left[\begin{array}{ll}i_{t} & \pi_{t}\end{array}\right]$. The vector of error terms $\varepsilon=\left[\begin{array}{ll}\varepsilon_{i}, & \varepsilon_{\pi}\end{array}\right] \sim \mathrm{N}(0, \Omega)$ where $\Omega$ is positive definite and given by:

$$
\Omega=\left[\begin{array}{ll}
\omega_{i i} & \omega_{i \pi} \\
\omega_{i \pi} & \omega_{\pi \pi}
\end{array}\right]
$$

Manipulation of Eq.(4) allows this VAR model to be re-specified as a vector error correction model (VECM):

$$
\Delta Y_{t}=\mu+\lambda Y_{t-1}+\sum_{j=1}^{p-1} \gamma_{j} \Delta Y_{t-j}+\varepsilon_{t}
$$

where the short-run coefficients are given by:

$$
\gamma_{j}=\left[\begin{array}{ll}
\gamma_{i i, j} & \gamma_{i \pi, j} \\
\gamma_{\pi i, j} & \gamma_{\pi \pi, j}
\end{array}\right]=-\sum_{k=j+1}^{p} \phi_{k}
$$

The coefficient $\lambda$ is the long-run multiplier matrix and is given by:

$$
\lambda=\left[\begin{array}{cc}
\lambda_{i i} & \lambda_{i \pi} \\
\lambda_{\pi i} & \lambda_{\pi \pi}
\end{array}\right]=-\left(I_{2}-\sum_{j=1}^{p} \phi_{j}\right)
$$

where $I_{2}$ is a $2 \times 2$ identity matrix. The diagonal elements of the matrix $\lambda$ are left unrestricted, allowing for the possibility that the series can be either $\mathrm{I}(0)$ or $\mathrm{I}(1)$. The bounds test procedure allows for the testing of at most one long-run relationship and so requires a zero restriction on one of the off diagonals of the matrix $\lambda$. As we test for the Fisher effect, we impose the assumption that $\lambda_{\pi i}=0$. Under this assumption, the equation for the nominal interest rate from Eq.(6) can be written as:

$$
\Delta i_{t}=\theta_{0}+\theta_{1} i_{t-1}+\theta_{2} \pi_{t-1}+\sum_{i=1}^{m} \gamma_{1 i} \Delta i_{t-i}+\sum_{i=0}^{n} \gamma_{2 i} \Delta \pi_{t-i}+\mu_{t}
$$

The presence of cointegration between nominal interest rate and inflation is tested by restricting the lagged levels variables and intercept in the above equation equal to zero, i.e. $\theta_{0}=\theta_{1}=\theta_{2}=0$. This hypothesis is tested by the mean of the F-statistic. Pesaran et al. (2001) suggested applying the cumulative sum of recursive residuals (CUSUM) and the cumulative sum of recursive of squares of recursive residuals (CUSUMSQ) tests to assess the parameter constancy of the model.

\section{Empirical Results}

As a first step of our empirical analysis, we test for the order of integration of the two series. This step is important in order to ensure that no variable is integrated of order two or higher. Moreover, the bounds test requires the dependent variable to be integrated of order one. To this end, we perform two well-known unit root tests- the PP test of Phillips-Perron (1988) and the KPSS test of Kwiatkowski et al. (1992). These tests have been performed under the models with constant and trend for the level series and with constant for series in first difference. The results of these tests are displayed in Table 1. They show that nominal interest rate is I(1) and inflation is stationary for all countries, except Nigeria for which inflation is I(1). These results suggest that the necessary conditions for standard cointegration tests of the Fisherian relationship between nominal interest rates and inflation do not hold. Therefore, the Fisher equation cannot be tested using standard techniques, since it is "unbalanced", in the terminology of $\mathrm{Ng}$ and Perron (1997). These results provide rational to the bounds testing approach. 
Table 1. Results of unit root tests

\begin{tabular}{|c|c|c|c|c|c|c|c|c|c|}
\hline \multirow[t]{2}{*}{ Country } & \multirow[t]{2}{*}{ Time period } & \multicolumn{4}{|c|}{ Phillips-Perron Test } & \multicolumn{4}{|c|}{ KPSS Test } \\
\hline & & $i$ & $\pi$ & $\Delta i$ & $\Delta \pi$ & $i$ & $\pi$ & $\Delta i$ & $\Delta \pi$ \\
\hline Benin & 1971-2013 & -3.37 & $-4.84^{*}$ & $-6.59^{*}$ & $-26.21^{*}$ & 0.14 & 0.06 & 0.18 & 0.05 \\
\hline Cameroon & $1979-2013$ & -3.33 & $-5.11^{*}$ & $-6.33^{*}$ & $-19.10^{*}$ & 0.12 & 0.05 & 0.20 & 0.31 \\
\hline Cote d'Ivoire & $1970-2013$ & -2.92 & $-4.32^{*}$ & $-6.68^{*}$ & $-8.70^{*}$ & $0.15^{*}$ & 0.05 & 0.18 & 0.06 \\
\hline Gabon & $1979-2013$ & -3.07 & $-4.71^{*}$ & $-6.26^{*}$ & $-12.98^{*}$ & 0.12 & 0.09 & 0.26 & 0.23 \\
\hline Gambia & $1978-2013$ & -2.13 & $-3.54^{* *}$ & $-6.01^{*}$ & $-10.57^{*}$ & 0.13 & 0.07 & 0.40 & 0.20 \\
\hline Ghana & $1978-2013$ & -1.61 & $-6.57^{*}$ & $-6.14^{*}$ & $-22.76^{*}$ & $0.17^{*}$ & 0.11 & 0.14 & 0.23 \\
\hline Kenya & $1970-2013$ & -1.76 & $-3.87^{*}$ & $-6.17^{*}$ & $-8.50^{*}$ & $0.17^{*}$ & 0.08 & 0.13 & 0.13 \\
\hline Nigeria & $1970-2013$ & -1.87 & -3.02 & $-8.13^{*}$ & $-12.37^{*}$ & $0.18^{*}$ & $0.15^{*}$ & 0.21 & 0.05 \\
\hline Senegal & $1970-2013$ & -2.92 & $-5.43^{*}$ & $-6.68^{*}$ & $-18.55^{*}$ & $0.15^{*}$ & 0.04 & 0.18 & 0.41 \\
\hline South Africa & $1977-2013$ & -1.53 & $-3.55^{*}$ & $-4.00^{*}$ & $-8.66^{*}$ & $0.19^{*}$ & 0.10 & $0.50^{*}$ & 0.17 \\
\hline
\end{tabular}

Notes. $\mathrm{i}$ and $\pi$ are the symbols for nominal interest rate and inflation rate, respectively. $*(* *)$ denotes rejection of the null hypothesis at the $5 \%$ $(10 \%)$ level.

Next, we apply the bounds test to examine the long-run relationship between the two variables. The results are reported in Table 2. Lag length on each variable is selected using the general-to-specific approach, with maximum lag set to five. In the case where the null of no long-run relationship is rejected, we also report the estimates of the parameters of the Fisher equation. As can be seen from Table 2, the computed F-statistic is greater than the lower bounds for critical values at the 5\% level for Cameroon, Cote d'Ivoire, Gabon, Gambia and Kenya, suggesting the rejection of the null of no cointegration. However, as suggested by the bounds procedure described in Pesaran et al. (2001), we further examine the t-statistic of the coefficients in order to unravel the case of degenerate long-run relationships. Of the five countries, the coefficient on interest rate is significant only for Cote d'Ivoire, Gabon and Kenya. We conclude that a long-run relationship between nominal interest rates and inflation exists for these three countries. For the other seven countries, there is no evidence of long-run relationship between nominal interest rates and inflation. Our result for Nigeria is in line with those of Asemota and Bala (2011) and Ogbonna (2013).

Table 2. Results of bounds test for cointegration

\begin{tabular}{lccccc}
\hline Country & F-stat & t-stat $\left(\theta_{1}\right)$ & \multicolumn{3}{c}{ Fisher equation } \\
\cline { 3 - 5 } & & & Constant $(\alpha)$ & Inflation $(\beta)$ & $\beta=1$ \\
\hline Benin & 2.595 & -2.072 & & & \\
Cameroon & $4.323^{*}$ & 1.508 & & & \\
Cote d'Ivoire & $13.817^{*}$ & $-6.435^{*}$ & $4.774(7.83)^{*}$ & $0.046(1.29)$ & $-26.34(0.000)^{*}$ \\
Gabon & $5.689^{*}$ & $-2.594^{* *}$ & $2.995(2.17)^{*}$ & $0.520(2.39)^{*}$ & $-2.19(0.039)^{*}$ \\
Gambia & $7.522^{*}$ & -0.74 & & & \\
Ghana & 1.230 & -1.551 & & & \\
Kenya & $5.889^{*}$ & $-3.592^{*}$ & $-1.080(-0.320)$ & $0.817(3.24)^{*}$ & $-0.72(0.474)$ \\
Nigeria & 1.242 & -1.624 & & & \\
Senegal & 2.399 & -2.351 & & & \\
South Africa & 2.051 & -2.336 & & & \\
\hline
\end{tabular}

Note. Critical values for F-statistics and t-statistics are from Pesaranet al. (2001). *(**) denotes significance at the 5\% (10\%) level.

We next look at the long-run estimates of the Fisher effect. For the Fisher hypothesis to hold, the coefficient on inflation should equal one. The relationship between nominal interest rate and inflation is positive but the null hypothesis of $\beta=1$ is rejected for Cote d'Ivoire and Gabon, providing evidence in favor of the partial Fisher effect. This result implies a negative relationship between real interest rate and inflation rate. On the contrary, the full Fisher hypothesis holds in the case of Kenya.

\section{Conclusion}

This study tested the validity of the long-run Fisher effect for ten African countries. The results from the bounds test indicate that there exists a long-run relationship between nominal interest rate and inflation in three countries. Further, we estimated the long-run relation and found that the full Fisher effect holds only in Kenya. We found a 
positive but less than one-for-one reaction of interest rate to inflation in Cote d'Ivoire and Gabon, lending support to the partial Fisher effect in these two countries. Conversely, for the other seven countries, the results suggest no evidence of long-run relationship between nominal interest rates and inflation.

From these findings we conclude that the full long-run Fisher effect does not generally hold in African countries. This result may be due to the fact that the interest rates in African economies are mostly administered. Partial Fisher effect implies that money is not super neutral and that there is money illusion, if assumption is made that money growth drives inflation, because real interest rate is affected by inflation. Following Fisher (1930), there was some kind of money illusion in which economic agents do not take full account of the effect of inflation on their nominal return. However, money illusion would imply that economic agents are irrational. An alternative explanation is provided by Mundell (1963) and Tobin (1965) in terms of a "wealth effect". Inflation results in a fall in real money balances and the resulting decline in wealth leads to increased savings bringing downward pressure on real interest rates. Another strand of literature considers that structural changes and nonlinearities due to shifts in monetary policy changes, financial crises or technological changes, may explain the apparent failure of Fisher effect in the empirical literature. It is well known by now that structural changes and nonlinearities lower the power of cointegration tests. We intend to investigate this issue in future research.

\section{References}

Ahmad, S. (2010a). The long-run Fisher effect in developing economies. Studies in Economics and Finance, 27(4), 268-275. http://dx.doi.org/10.1108/10867371011085129

Ahmed, S. (2010b). Fisher effect in nonlinear STAR framework: Some evidence from Asia. Economics Bulletin, $30,2558-2566$.

Arisoy, I. (2013). Testing for the Fisher Hypothesis under Regime Shifts in Turkey: New Evidence from Time-Varying Parameters. International Journal of Economics and Financial Issues, 3(2), 496-502.

Asemota, J. O., \& Bala, A. D. (2011). A Kalman Filter Approach to Fisher Effect: Evidence from Nigeria. CBN Journal of Applied Statistics, 2(1), 71-91.

Atkins, F. J., \& Coe, P. J. (2002). An ARDL bounds test of the long-run Fisher effect in the United States and Canada. Journal of Macroeconomics, 24(2), 255-266. http://dx.doi.org/10.1016/S0164-0704(02)00019-8

Awomuse, B. O., \& Alimi, S. R. (2012). The relationship between nominal interest rates: New evidence and implications for Nigeria. Journal of Economic and Sustainable Development, 3(9), 158-165.

Badillo, R., Reverte, C., \& Rubio, E. (2011). The Fisher effect in the EU revisited: New evidence using panel cointegration estimation with global stochastic trends. Applied Economics Letters, 18(13), 1247-1257.

Bajo-Rubio, O., Diaz-Roldan, C., \& Esteve, V. (2005). Is the Fisher Effect nonlinear? Some evidence from Spain, 1963-2002. Applied Financial Economics, 15, 849-854. http://dx.doi.org/10.1080/09603100500123187

Bonham, C. S. (1991). Correct Cointegration Test of the long-run relationship between Nominal Interest and Inflation. Applied Economics, 23(9), 1487-1492.

Carneiro, F. G., Angelo, J., Divino, C. A., \& Rocha, C. (2002). Revisiting the Fisher hypothesis for the cases of Argentina, Brazil, and Mexico. Applied Economics Letters, 9, 95-98. http://dx.doi.org/10.2139/ssrn.289824

Crowder, W. J., \& Hoffman, D. L. (1996). The long-run relationship between nominal interest rates and inflation: The Fisher equation revisited. Journal of Money, Credit and Banking, 28, 102-118.

Dutt, S. B., \& Ghosh, D. (2007). A threshold cointegration test of the Fisher hypothesis: Case study of 5 European nations. Southwestern Economic Review, 341, 41-50.

Evans, M. D. D., \& Lewis, K. K. (1995). Do expected shifts in inflation affect estimates of the long-run Fisher relation? Journal of Finance, 50(1), 225-253. http://dx.doi.org/10.2307/2329244

Fisher, I. (1930). The Theory of Interest. New York: MacMillan.

Garcia, M. G. P. (1993). The Fisher effect in a signal extraction framework: The recent Brazilian experience. Journal of Development Economics, 41, 71-93.

Ghazali, N. A., \& Ramlee, S. (2003). A long memory test of the long-run Fisher effect in the G7 countries. Applied Financial Economics, 13(20), 763-769.

Granville, B., \& Mallick, S. (2004). Fisher hypothesis: UK evidence over a century. Applied Economics Letters, $11(2), 87-90$.

Gul, E., \& Acikalin, S. (2008). An examination of the Fisher hypothesis: The case of Turkey. Applied Economics, 
40(24), 3227-3231. http://dx.doi.org/10.1080/00036840600994112.

Hall, S. G., Hondroyiannis, G., Swamy, P. V., \& Tavlas, G. S. (2010). The Fisher Effect Puzzle: A Case of Non-Linear Relationship? Open Economics Review, 21(1), 91-103. http://dx.doi.org/10.1007/s11079-009-9157-1

Hatemi, J. A. (2009). The International Fisher effect: Theory and Application. Investment management and Financial Innovations, 6, 75-79.

Hatemi, J. A., \& Irandoust, M. (2008). The Fisher Effect: A Kalman Filter Approach to detecting Structural Change. Applied Economics Letters, 15(8), 619-624. http://dx.doi.org/10.1080/13504850600721924

Inder, B., \& Silvapulle, P. (1993). Does the Fisher effect apply in Australia? Applied Economics, 25(6), 839-843. http://dx.doi.org/10.1080/00036849300000138

Ito, T. (2009). Fisher hypothesis in Japan: Analysis of long-term interest rates under different monetary policy regimes. World Economy, 32(7), 1019-1035. http://dx.doi.org/10.1111/j.1467-9701.2009.01193.x

Johansen, S. (1988). Statistical Analysis of cointegration vectors. Journal of Economic Dynamics and Control, $12,231-254$.

Johansen, S., \& Juselius, K. (1990). Maximum likelihood estimation and inference on cointegration with application to the demand for money. Oxford Bulletin of Economics and Statistics, 52, 169-210.

Koustas, Z., \& Serletis, A. (1999). On the Fisher Effect. Journal of Monetary Economics, 44(1), 105-130.

Kwiatkowski, D., Phillips, P. C. B., Schmidt, P., \& Shin, Y. (1992). Testing the null hypothesis of stationarity against the alternative of a unit root. Journal of Econometrics, 54(1-3), 159-178.

Mishkin, F. S. (1992). Is the Fisher effect for real? A re-examination of the relationship between inflation and

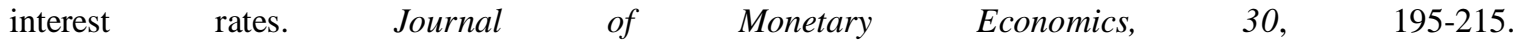
http://dx.doi.org/10.1016/0304-3932(92)90060-F

Mitchell-Innes, H. A., Aziakpono, M. J., \& Faure, A. P. (2008). Inflation targeting and the Fisher effect in South Africa: An empirical investigation. South African Journal of Economics, 75(4), 693-707.

Mundell, R. (1963). Inflation and real interest. The Journal of Political Economy, 71, 280-283.

Muse, B., \& Alimi, R. (2012). Testing an augmented Fisher hypothesis for small open economy: The case of Nigeria. Akangha Journal of Management, 4(1), 33-44.

Ng, S., \& Perron, P. (1997). Estimation and Inference in Nearly Unbalanced Nearly Cointegrated Systems. Journal of Econometrics, 73, 53-81.

Nusair, S. A. (2008). Testing for the Fisher hypothesis under regime shifts: An application to Asian countries. International Economic Journal, 22(2), 273-284. http://dx.doi.org/10.1080/10168730802095660.

Obi, B., Nurudeen, A., \& Wafure, O. B. (2009). An empirical investigation of the Fisher effect in Nigeria: A cointegrtion and error correction approach. International Review of Business Research Papers, 5(5), 96-109.

Ogbonna, B. C. (2013). Testing for Fisher's hypothesis in Nigeria (1970-2012). Journal of Economics and Sustainable Development, 4(16), 163-170.

Payne, J. E., \& Ewing, B. T. (1997). Evidence from lesser developed countries on the Fisher Hypothesis: A Cointegration Analysis. Applied Economics Letters, 4(11), 683-687.

Pesaran, H., Shin, Y., \& Smith, R. J. (2001). Bounds Testing Approaches to the Analysis of Level Relationships. Journal of Applied Econometrics, 16(3), 289-326. http://dx.doi.org/10.1002/jae.616

Phillips, P. C. B., \& Hansen, B. E. (1990). Statistical inference in instrumental variables regression with I(1) processes. Revue of Economics Studies, 57, 99-125.

Phillips, P. C. B., \& Perron, P. (1988). Testing for a Unit Root in a Time Series Regression. Biometrika, 75(2), 335-346.

Phiri, A., \& Lusanga, P. (2011). Can asymmetries account for the empirical failure of the Fisher effect in South Africa? Economics Bulletin, 31(3), 1968-1979.

Saikkonen, P. (1991). Asymptotically efficient estimation of cointegrationregressions. Econometrics Theory, 7, $1-21$. 
Sheefeni, J. P. S. (2013). Testing for the Fisher Hypothesis in Namibia. Journal of Emerging Issues in Economics, Finance and Banking, 2(1), 571-582.

Stock, J. H., \& Watson, M. W. (1993). A simple estimator of cointegrating vectors in higher order integrated systems. Econometrics, 61, 783-820.

Thornton, J. (1996). The adjustment of nominal interest rates in Mexico: A study of the Fisher effect. Applied Economics Letters, 3, 255-257.

Tobin, J. (1965). Money and Economic Growth. Econometrica, 33, 671-684.

Toyoshima, Y., \& Hamori, S. (2011). Panel cointegration analysis of the Fisher effect: Evidence from the US, the UK, and Japan. Economics Bulletin, 31(3), 2674-2682.

Ucak, H., Ozturk, I., \& Aslan, A. (2014). An Examination of Fisher Effect for Selected New EU Member States. International Journal of Economics and Financial Issues, 4(4), 956-959.

Ur, H., Khan, S., \& Ahmad, I. (2004). Does Fisher Effect Exist in Pakistan? A Cointegration Analysis. Pakistan Economic and Social Review, 42(1-2), 21-37.

Westerlund, J. (2008). Panel cointegration tests of the Fisher Effect. Journal of Applied Econometrics, 23(2), 193-233. http://dx.doi.org/10.1002/jae.967

Yuhn, K. (1996). Is the Fisher effect robust? Further evidence. Applied Economics Letters, 3(1), 41-44.

\section{Copyrights}

Copyright for this article is retained by the author(s), with first publication rights granted to the journal.

This is an open-access article distributed under the terms and conditions of the Creative Commons Attribution license (http://creativecommons.org/licenses/by/3.0/). 